\title{
Distribution of sedimentary rock types through time in a back-arc basin: A case study from the Jurassic of the Greater Caucasus (Northern Neotethys)
}

\author{
Dmitry A. Ruban
}

\begin{abstract}
The evolution of sedimentary basins can be explored by analyzing the changes in their lithologies and lithofacies (i.e. predominant lithologies). The Greater Caucasus Basin, which was located at the northern margin of the Neotethys Ocean, represents a complete Sinemurian-Tithonian succession. A quantitative analysis of compiled datasets suggests that principal lithologies and lithofacies are represented by siliciclastics, shale and carbonates. The relative abundance of siliciclastics and shale decreased throughout the Jurassic, whereas that of carbonates increased. Evaporites are known from the Upper Jurassic, while volcaniclastics and volcanics, as well as coals, are known only in the Lower to Middle Jurassic. Siliceous rocks are extremely rare. Lithology and lithofacies proportions change accordingly. The Sinemurian-Bathonian sedimentary complex is siliciclastic-and-shale-dominated, whereas the Callovian-Tithonian sedimentary complex is carbonate-dominated. A major change in the character of sedimentation occurred during the Aalenian-Callovian time interval. Regional transgressions and regressions were more important controls of changes in the sedimentary rock proportions than average basin depth. Landward shoreline shifts were especially favorable for carbonate accumulation, whereas siliciclastics and shale were deposited preferentially in regressive settings. An extended area of the marine basin, its lower average depth, and a sharp bathymetric gradient favored a higher diversity of sedimentation. An orogeny at the Triassic-Jurassic transition was responsible for a large proportion of siliciclastics and extensive conglomerate deposition. An arcarc collision in the Middle Jurassic also enhanced the siliciclastic deposition. Both phases of tectonic activity were linked with an increase in volcanics and volcaniclastics. Volcanism itself might have been an important control on sedimentation. A transition to carbonate-dominated sedimentation occurred in the Late Jurassic, reflecting a tectonically calm period.
\end{abstract}

Key words: lithology, sedimentary basin, Jurassic, rock proportions, lithofacies, Greater Caucasus, northern Neotethys

Address: $\quad$ D. A. Ruban: P. O. Box (a/jashik) 7333, Rostov-na-Donu, 344056, Russian Federation e-mails: ruban-d@mail.ru, ruban-d@rambler.ru

Received: April 9, 2009; accepted: May 14, 2009 


\section{Introduction}

The methods of sequence stratigraphy and basin analysis are effective for interpretation of the architecture and evolution of sedimentary basins (e.g. Boggs 2006; Catuneanu 2006; Veeken 2006; Catuneanu et al. 2009). The assessment of variations in the quantities of sedimentary rock types may yield important clues to general patterns of sedimentation dynamics. Such studies were attempted on a global scale by Ronov et al. (1980). Peters (2006) investigated the proportions of common Phanerozoic rock types in North America. Quantitative evaluation of rock proportions is a suitable tool to explore particular sedimentary basins of different types. Peters (2006) revitalizes previous discussions on general trends in variation of particular rock types through geologic time.

The Greater Caucasus Basin, which was located at the northern active margin of the Neotethys Ocean in the Jurassic (Fig. 1), has a diverse and well-studied sedimentary record and provides an exceptional opportunity to study the changes in rock proportions through time. Coarse to fine-grained siliciclastic, carbonate, evaporite, coal, and siliceous deposits, as well as volcaniclastic and volcanic rocks, have been described from this basin (Prozorovskaya 1979; Rostovtsev et al. 1992; Ruban 2007a, 2008a, b). As shown by a recently published

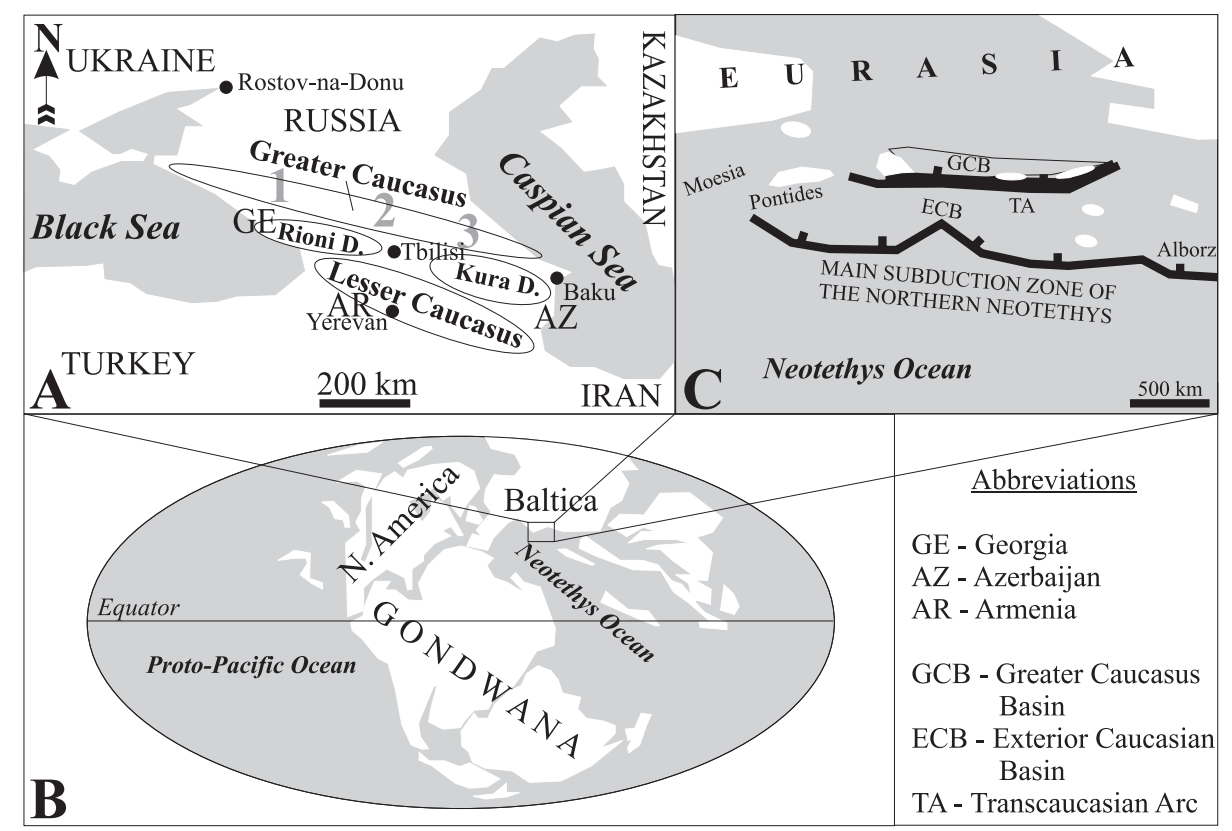

Fig. 1

Present location of the Greater Caucasus (A), regional Middle Jurassic paleogeographic sketch map (after Ruban 2006b) (B), and global Jurassic tectonics (after Scotese, 2004) (C). Numbers 1-3 on A indicate reference areas for composite stratigraphic sections presented in Fig. 2 
synthesis (Ruban 2007a), relative proportions of these rocks changed not only temporally, but also geographically. A dramatic change took place at the Middle-Late Jurassic transition with a shift from siliciclastic to carbonate rocks. Moreover, recent studies made it possible to outline the Jurassic evolution of the Greater Caucasus Basin and, thus, allowed a discussion of the nature of the changes in sedimentary rock proportions. Jurassic transgressions and regressions of the Caucasus region were reconstructed (Ruban 2006a, 2007a, 2008b) and compared with the global eustatic curves (Haq et al. 1987; Hallam 1988, 2001; Haq and Al-Qahtani 2005). New tectonic models were proposed for the study region (Ershov et al. 2003; Kazmin and Tikhonova 2006; Ruban 2006b, 2007b, 2008a; Saintot et al. 2006; Tawadros et al. 2006) and they were fitted to the global plate tectonic reconstructions (Dercourt et al. 2000; Stampfli and Borel 2002; Golonka 2004; Scotese 2004).

The Greater Caucasus Basin is regarded as a back-arc basin, located in a key position between the structural domains of Southern Europe and the Middle East. An evaluation of its sedimentary evolution during the Jurassic is particularly important because it can demonstrate some patterns common to other back-arc basins. It is expected that this study may provide a kind of framework for a quantitative analysis of the basin-wide character of sedimentary processes.

\section{Geologic setting}

The mountain range of the Caucasus, which is more than $1100 \mathrm{~km}$ long, lies between the Black Sea and the Caspian Sea. It covers an area of about 400,000 $\mathrm{km}^{2}$. It consists of the Greater Caucasus, the object of the present study, the Lesser Caucasus, and the Transcaucasian Depressions (Fig. 1). A number of particular areas are distinguished within this region for each major geologic time slice on the basis of their sedimentary successions and facies. Traditionally, they are called "structural-facial zones" (e.g. Rostovtsev et al. 1992). The size of these areas varies, but it is generally measured by thousands of $\mathrm{km}^{2}$.

The geology of the Caucasus, with a special emphasis on the Jurassic, was reviewed recently by Ershov et al. (2003), Kazmin and Tikhonova (2006), Ruban (2006a, b; 2007a, b; 2008a, b), Saintot et al. (2006), Tawadros et al. (2006), and Efendiyeva and Ruban (2009). Many questions on the regional geology, however, remain open. Generally, the Greater Caucasus is interpreted as a Gondwanaderived terrane that docked at the Laurussian margin of the Paleotethys Ocean in the Late Devonian. It was translated to its present position at the southern edge of the Russian Platform along a major shear zone in the Late Triassic-earliest Jurassic. A back-arc basin evolved there until the Late Cenozoic when an orogeny began. The arc complexes are now exposed within the southern structures of the Greater Caucasus. 
In the Jurassic, the Greater Caucasus Basin was situated on the northern active margin of the Neotethys Ocean (Fig. 1). It was an asymmetrical basin with a steep southern slope and a gentle northern slope. The basin was bounded to the south by an island arc, whereas it was connected with the epicontinental shallowmarine basins of the Russian Platform to the north (Ruban 2006b). Hettangian strata are absent in the Greater Caucasus. The Sinemurian-Bathonian interval is dominated by siliciclastic deposits with a total thickness of up to $10 \mathrm{~km}$, and it includes some volcanics and volcaniclastics (Rostovtsev et al. 1992; Ruban 2007a,

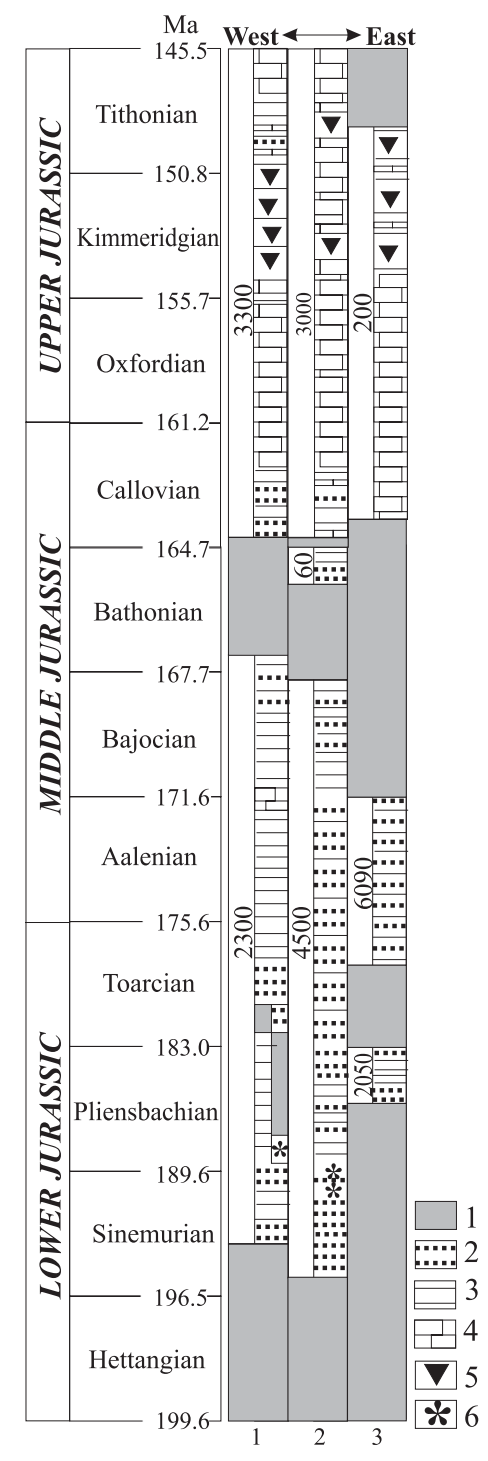
2008a, b). The Callovian-Tithonian interval has a total thickness of about $3.5 \mathrm{~km}$ (Rostovtsev et al. 1992; Ruban 2007a, 2008a, b) and is dominated by carbonate rocks. Evaporites occur in the upper part of this interval (Fig. 2). There are two major unconformities, one at the base of the Lower Jurassic deposits and the other between the Bathonian and Callovian strata. Their interpretation is controversial (Ruban 2007b).

The regional Jurassic paleoenvironments were reviewed by Jasamanov (1978) and Ruban (2006a, 2007a, 2008a). The sea was generally warm, of normal salinity, and well populated by marine organisms. There were three outstanding events in the evolution of this basin, namely oxygen depletion in the Toarcian (Ruban 2004, 2008a; Ruban and Tyszka 2005), carbonate platform development in the Callovian-Tithonian (Kuznetsov 1993; Ruban 2005, 2006a, 2008a), and salinity crisis in the Kimmeridgian-Tithonian (Ruban 2006a, 2008a). Ruban (2007a, 2008b) recognized stepwise transgressions in the Sinemurian-Toarcian and the CallovianKimmeridgian and deepening pulses in the Pliensbachian, Aalenian and Bathonian.

Fig. 2

Composite stratigraphic sections of the Jurassic deposits of the Greater Caucasus (modified after Ruban 2007a). See Fig. 1 for localities. Time scale after Ogg et al. (2008). Lithology: 1. hiatus (no deposits), 2. siliciclastics (conglomerates, sandstones, and siltstones), 3. shales, 4 . carbonates, 5 . evaporites, 6 . volcanics and volcaniclastics. Thickness $(\mathrm{m})$ is indicated to the left of columns 


\section{Materials and methods}

\section{Rock proportions}

Changes in sedimentary rock proportions are described here in terms of both lithologies and lithofacies. Lithologies are the types of sedimentary rocks, whereas lithofacies are those sedimentary rock types (lithologies) that dominate a given sedimentary succession by thickness which follows the Peters definition (2006). The classification of sedimentary rocks used in the present study is based on that proposed by Boggs (2006), with, however, two important differences. Shale is distinguished from other siliciclastics because clay particles can be either detrital or authigenic (Chamley 1989; Weaver 1989; Velde 1992, 1995; Fagel 2007). Moreover, shale has physical properties different from siliciclastics. It seems that in the Greater Caucasus Basin most if not all shale is detrital. Thus, a combination of shale and siliciclastics was also considered. Siltstone is classed with siliciclastic lithologies because it contains less than 30\% clay particles (Boggs 2006). Thus, the following lithologies are distinguished in the present study: siliciclastics (conglomerate, sandstone and siltstone), shale, carbonates, evaporites, coals, volcaniclastics and volcanics, and siliceous rocks. More detailed analysis of lithologies, e.g. a distinction of carbonate rock types, is unnecessary because the present paper aims to explain only general trends. Although volcaniclastic rocks prevail over volcanic ones, both types occur together in some formations, and volcanic rocks may play a significant role in the sedimentary succession. Volcanic rocks were not excluded from the stratigraphic analysis attempted by Rostovtsev et al. (1992), nor are they omitted in this study.

The data compiled for this study are extracted from Rostovtsev et al. (1992) and Ruban (2007a) with some corrections based on field observations (see Appendix). The region of the Greater Caucasus could be divided into a number of areas differing by sedimentary successions and facies (Rostovtsev et al. 1992). Twentyeight areas were distinguished for the Sinemurian-Bathonian interval, and thirteen for the Callovian-Tithonian interval [see Ruban (2008b) for a location of these areas]. For the purposes of this study, lithologies and lithofacies have been established for each of the 158 Jurassic formations known in the Greater Caucasus. Most of the formations are characterized by a mixed composition. In order to evaluate the true proportions of the particular lithologies, combining several lithologies into one category is avoided herein.

The present analysis of the Jurassic rock proportions in the Greater Caucasus Basin is carried out at stage level. The Jurassic chronostratigraphy follows the recommendations of the International Commission on Stratigraphy (Ogg et al. 2008; see also www.stratigraphy.org). Although there were some differences in establishing formations in the former USSR, the Jurassic formations of the Greater Caucasus defined by Rostovtsev et al. (1992) fulfill the international requirement for these kind of lithostratigraphic units (Salvador 1994), and can thus be used in this study without any special caution. 
For the quantitative analysis, a simple equation is used:

$\mathrm{WS}=(\mathrm{NS} / \mathrm{N})^{*} 100$,

where WS is a lithology/lithofacies percentage in a given stage, NS is the number of formations irrespective of their thickness containing this lithology/lithofacies within a given stage, and $\mathrm{N}$ is the total number of formations irrespective of their thickness recognized within the study territory for a given stage. All correlations attempted with WS values are based on the Spearman's coefficient of pair correlation (Kendall 1970). The same formation can certainly exist in several areas under the same or a different name. This could potentially alter an evaluation of proportions with the WS index. However, this problem appears solved by the present study. We considered each formation from each area as a particular body. Thus, every Jurassic stage is characterized by data from the same number of areas.

\section{Transgressions, regressions and basin depth}

Transgression-regression and deepening-shallowing are distinct patterns of basin dynamics that should always be distinguished. The former represents shifts of the shoreline (Catuneanu 2006), whereas the latter reflects changes in the absolute depth of the basin. A distinction between them in the Jurassic history of the Greater Caucasus Basin was attempted by Ruban (2007a). Since the Sinemurian, deep-marine environments, usually identified by turbiditic successions, existed in at least one area of this basin. It is, therefore, better to estimate the average basin depth, expressed by the relative distribution of the areas with deep-marine environments.

An earlier evaluation of the Jurassic transgressions, regressions, and basin depth was attempted for the entire Caucasus (Ruban 2006a), which is not informative for the present study, which deals with a more restricted territory. Ruban $(2007 a, 2008 b)$ later calculated them for the Greater Caucasus Basin with a high precision. To compare transgressions, regressions, and basin depth with the changes in sedimentary rock proportions in this paper, information is required on the transgressions-regressions and the changes in the average basin depth determined for stages (thus, the scope of this study differs from those attempted by Ruban (2007a, 2008b)). To do this, we use two equations, which are derived from those proposed by Ruban (2006a):

$$
\begin{aligned}
& \mathrm{Tg}=(\mathrm{s}+\mathrm{d}) / \mathrm{c}, \\
& \mathrm{Da}=\mathrm{d} / \mathrm{s},
\end{aligned}
$$

where $\mathrm{Tg}$ - index of transgression, Da - index of average basin depth, c, s, d - the quantity of areas defined by Rostovtsev et al. (1992) and Ruban (2007a, 2008b) 
with continental, shallow-marine, and deep-marine environments, respectively. The paleoenvironmental data on the Greater Caucasus Basin presented by Ruban (2007a, 2008b) were used for calculations. In this study, shallow-marine environments characterize shelfal conditions, whereas the deep-marine ones characterize slope conditions, chiefly marked by turbidites. Such a simplistic dichotomy seems to be efficient to evaluate the average basin depth in very general values. Very few typically continental deposits occur in the Greater Caucasus Basin (Ruban 2008b). They are accounted for in this study. It is sensible to note that these continental deposits were formed near the shoreline and, thus, their accumulation was influenced by the dynamics of the latter (Catuneanu 2006). However, most continental facies are established on the basis of observed hiatuses. A difference between subaerial and subaqueous volcanism-related facies was also made. A comparison of Tg, Da, and WS values was attempted in this study with the Spearman's coefficient of pair correlation (Kendall 1970).

\section{Sedimentary rock type proportions for the entire Jurassic}

The Jurassic deposits of the Greater Caucasus Basins include many kinds of sedimentary rocks. All of these rock types may be predominant and accordingly can be defined as lithofacies, except for siliceous rocks, which do not dominate any of the Jurassic formations in this basin. A calculation of sedimentary rock proportions for the entire sedimentary succession provides some insightful results (Table 1). The Jurassic deposits of the Greater Caucasus Basin are evidently dominated by siliciclastics and shale, which occur in the majority of formations. Carbonates are less abundant and are present in less than half of the formations, whereas volcaniclastics and volcanics are present in a quarter of the formations. Evaporites, coals, and siliceous rocks are rare. The results of the lithofacies-based

Table 1

Sedimentary rock proportions for the Jurassic in the Greater Caucasus Basin

\begin{tabular}{|l|c|c|c|c|c|c|c|c|}
\hline $\begin{array}{l}\text { Rock proportions in } \\
\text { percent (WS) }\end{array}$ & Cla & Sha & $\begin{array}{c}\text { Cla }+ \\
\text { Sha }\end{array}$ & Car & Eva & Coa & Vol & Sci \\
\hline Lithology-based & 85 & 84 & 92 & 44 & 4 & 4 & 23 & 1 \\
\hline Lithofacies-based & 56 & 70 & 83 & 18 & 3 & 1 & 11 & 0 \\
\hline
\end{tabular}

NOTE: each formation can contain some lithologies and lithofacies, and, therefore, SWS $\neq 100 \%$. Lithologies: Cla - siliciclastics, sha - shales, Car - carbonates, Eva - evaporites, Coa - coals, Vol - volcanics and volcaniclastics, Sci - siliceous rocks

calculations are somewhat different. The most common predominant rock type is shale, whereas siliciclastics dominate about a half of the formations. The percentages of predominant carbonates and volcaniclastics and volcanics in the regional Jurassic sedimentary complexes are low. 
The observed difference between lithology- and lithofacies-based analyses of sedimentary rock proportions can be explained with the assumption that siliciclastics, carbonates, and volcaniclastics and volcanics occur in two modes, as forming relatively thick units and as rare interbeds. In contrast, shale preferentially forms thick layers or participates in rock alternations. Shale occurs in 132 formations and dominates $110(83 \%)$ of them. In comparison, siliciclastics dominate in only $66 \%$. One may hypothesize that a deposition of shale occurred preferentially en masse. Submarine slumping of thick Lower-Middle Jurassic dark-colored shale (Granovskij et al. 2001) confirms this indirectly. Our data (Table 2) suggest that a bimodal deposition like that of siliciclastics was also typical for carbonates.

Table 2

Number of occurrences (upper number) and WS (lower number) of Jurassic lithologies in the Greater Caucasus Basin. In the "Stage" column, values in brackets below mean the entire numbers of formations

\begin{tabular}{|c|c|c|c|c|c|c|c|c|}
\hline \multirow[t]{2}{*}{ Stage } & \multicolumn{8}{|c|}{ Lithologies } \\
\hline & Cla & Sha & $\begin{array}{l}\text { Clat } \\
\text { Sha }\end{array}$ & Car & Eva & Coa & Vol & Sci \\
\hline $\begin{array}{l}\text { Sin } \\
(16)\end{array}$ & $\begin{array}{c}16 \\
\mathbf{1 0 0}\end{array}$ & $\begin{array}{l}15 \\
94 \\
\end{array}$ & $\begin{array}{c}16 \\
\mathbf{1 0 0} \\
\end{array}$ & $\begin{array}{c}7 \\
44 \\
\end{array}$ & - & $\begin{array}{c}2 \\
13 \\
\end{array}$ & $\begin{array}{l}10 \\
63\end{array}$ & - \\
\hline $\begin{array}{l}\text { Pli } \\
(40)\end{array}$ & $\begin{array}{l}38 \\
95 \\
\end{array}$ & $\begin{array}{l}38 \\
\mathbf{9 5} \\
\end{array}$ & $\begin{array}{c}40 \\
\mathbf{1 0 0}\end{array}$ & $\begin{array}{l}13 \\
\mathbf{3 3} \\
\end{array}$ & - & $\begin{array}{l}3 \\
8 \\
\end{array}$ & $\begin{array}{l}16 \\
\mathbf{4 0} \\
\end{array}$ & - \\
\hline $\begin{array}{l}\text { Toa } \\
\text { (43) }\end{array}$ & $\begin{array}{l}42 \\
\mathbf{9 8} \\
\end{array}$ & $\begin{array}{l}41 \\
95\end{array}$ & $\begin{array}{c}43 \\
\mathbf{1 0 0} \\
\end{array}$ & $\begin{array}{l}10 \\
23\end{array}$ & - & $\begin{array}{l}1 \\
2\end{array}$ & $\begin{array}{c}8 \\
19 \\
\end{array}$ & - \\
\hline $\begin{array}{l}\text { Aal } \\
(31)\end{array}$ & $\begin{array}{l}30 \\
97 \\
\end{array}$ & $\begin{array}{l}30 \\
97 \\
\end{array}$ & $\begin{array}{l}30 \\
97 \\
\end{array}$ & $\begin{array}{c}9 \\
29 \\
\end{array}$ & - & $\begin{array}{l}1 \\
3 \\
\end{array}$ & $\begin{array}{c}4 \\
13 \\
\end{array}$ & - \\
\hline $\begin{array}{l}\text { Baj } \\
(27)\end{array}$ & $\begin{array}{l}20 \\
74\end{array}$ & $\begin{array}{l}23 \\
85 \\
\end{array}$ & $\begin{array}{l}23 \\
85\end{array}$ & $\begin{array}{l}12 \\
\mathbf{4 4} \\
\end{array}$ & - & - & $\begin{array}{l}11 \\
41 \\
\end{array}$ & $\begin{array}{l}1 \\
4 \\
\end{array}$ \\
\hline $\begin{array}{l}\text { Bat } \\
\text { (18) }\end{array}$ & $\begin{array}{l}17 \\
94 \\
\end{array}$ & $\begin{array}{l}14 \\
78 \\
\end{array}$ & $\begin{array}{c}18 \\
\mathbf{1 0 0}\end{array}$ & $\begin{array}{c}7 \\
39 \\
\end{array}$ & - & $\begin{array}{c}3 \\
17 \\
\end{array}$ & $\begin{array}{l}1 \\
6 \\
\end{array}$ & - \\
\hline $\begin{array}{l}\text { Cal } \\
\text { (16) }\end{array}$ & $\begin{array}{l}11 \\
69 \\
\end{array}$ & $\begin{array}{c}9 \\
56 \\
\end{array}$ & $\begin{array}{l}12 \\
75 \\
\end{array}$ & $\begin{array}{l}13 \\
81 \\
\end{array}$ & $\begin{array}{l}1 \\
6 \\
\end{array}$ & - & - & - \\
\hline $\begin{array}{l}\text { Oxf } \\
(16)\end{array}$ & $\begin{array}{l}10 \\
63 \\
\end{array}$ & $\begin{array}{l}11 \\
69 \\
\end{array}$ & $\begin{array}{l}13 \\
81 \\
\end{array}$ & $\begin{array}{l}15 \\
94 \\
\end{array}$ & - & - & - & - \\
\hline $\begin{array}{l}\text { Kim } \\
(16)\end{array}$ & $\begin{array}{l}12 \\
\mathbf{7 5} \\
\end{array}$ & $\begin{array}{l}11 \\
69 \\
\end{array}$ & $\begin{array}{l}14 \\
88 \\
\end{array}$ & $\begin{array}{l}15 \\
94 \\
\end{array}$ & $\begin{array}{c}3 \\
19 \\
\end{array}$ & - & - & - \\
\hline $\begin{array}{l}\text { Tit } \\
\text { (19) }\end{array}$ & $\begin{array}{l}11 \\
\mathbf{5 8}\end{array}$ & $\begin{array}{l}13 \\
68 \\
\end{array}$ & $\begin{array}{l}15 \\
79 \\
\end{array}$ & $\begin{array}{l}18 \\
\mathbf{9 5}\end{array}$ & $\begin{array}{c}5 \\
26 \\
\end{array}$ & - & - & - \\
\hline
\end{tabular}

Lithologies: $\mathrm{Cla}$ - siliciclastics, Sha - shales, Car - carbonates, Eva - evaporites, Coa - coals, Vol - volcanics and volcaniclastics, Sci - siliceous rocks. Stages: Sin - Sinemurian, Pli - Pliensbachian, Toa - Toarcian, Aal - Aalenian, Baj-Bajocian, Bat - Bathonian, Cal - Callovian, Oxf - Oxfordian, Kim - Kimmeridgian, Tit - Tithonian

\section{Changes in lithology proportions through time}

Lithology proportions changed markedly in the Greater Caucasus Basin throughout the Jurassic (Fig. 3; Table 2). The proportion of siliciclastic lithology generally decreased throughout the Jurassic. It dropped from $100 \%$ in the Sinemurian to $58 \%$ in the Tithonian. An abrupt decrease in the siliciclastic WS 

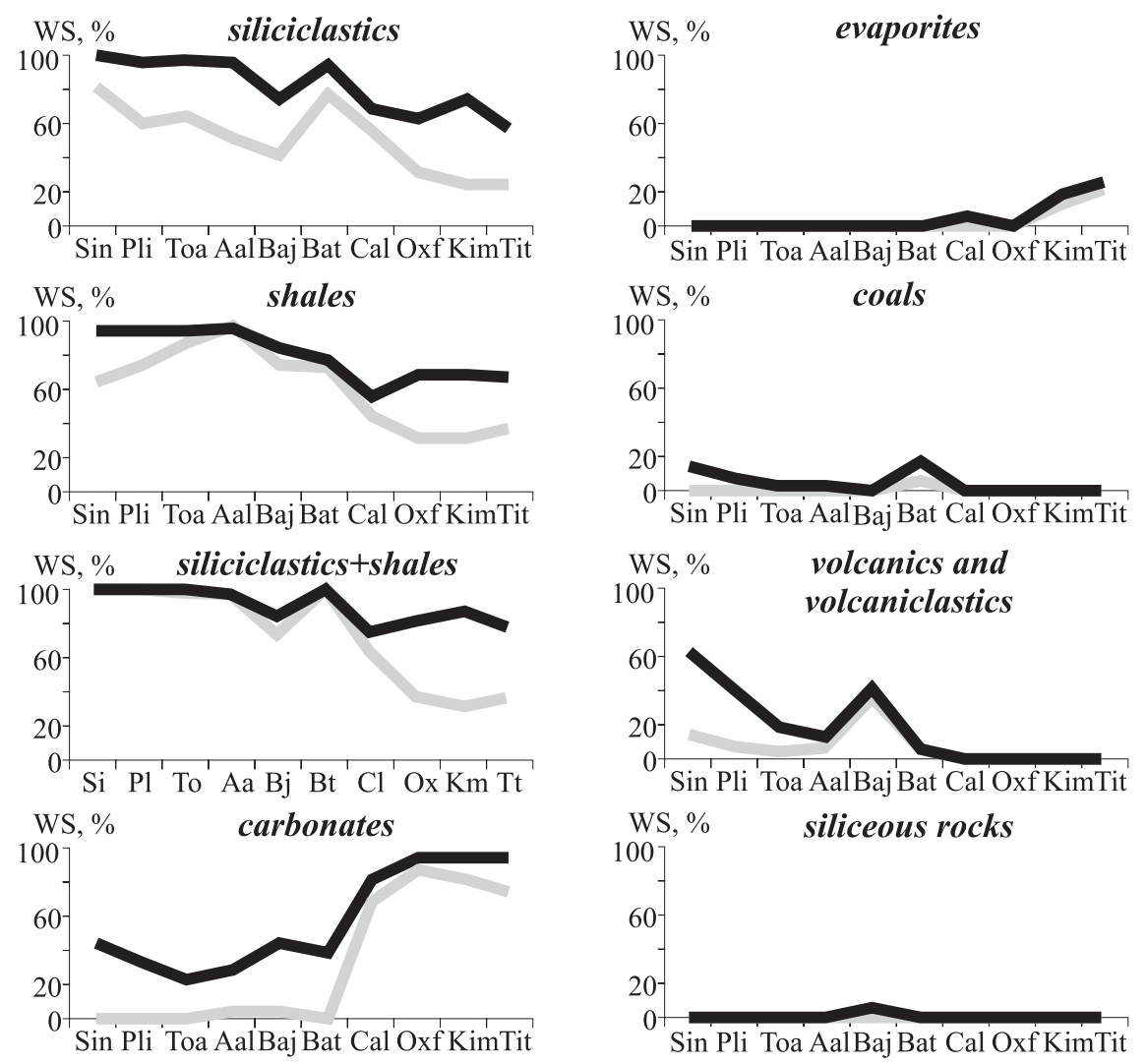

lithology proportion
lithofacies proportion

Fig. 3

Changes in lithology and lithofacies proportions throughout the Jurassic in the Greater Caucasus Basin

occurred in the Middle Jurassic. Meantime, a short-term peak took place in the Kimmeridgian, when the siliciclastic WS is comparable to that in the Bajocian. The proportion of shale was very high until the Bajocian, when it began to decline. However, an abrupt drop took place in the Callovian to be followed by a slight rebound in the Late Jurassic. The proportion of carbonates was relatively low until the Callovian, although the WS of this lithology registered for the Sinemurian and the Bajocian was not so low. Carbonate sedimentation prevailed in the Jurassic of the Greater Caucasus Basin from the Callovian onwards. Evaporites are known only in the Callovian-Tithonian interval, and their percentage in the Tithonian reached $26 \%$. In contrast, coal is known in the 
Sinemurian-Bathonian, and its WS values were high at the beginning and the end of this interval. Volcaniclastics contributed to the regional sedimentation until the Callovian only. Moreover, their proportions in the SinemurianPliensbachian and the Bajocian were comparable or even greater than those of carbonates. Siliceous rocks (chert) are found only in one formation of Bajocian age.

The above-mentioned changes in the WS values reflect the general mode of evolution of the Greater Caucasus Basin, where the siliciclastic-and-shaledominated sedimentation changed to carbonate-dominated at the BathonianCallovian transition. However, our quantitative data (Table 2) suggest that this shift was more complicated. A unidirectional decline of shale began earlier than that of siliciclastics (Fig. 3). The percentage of combined siliciclastics and shale already declined since the Bajocian; also, this trend was interrupted in the Bathonian (Table 2). A comparison of different stratigraphic intervals by their lithologies (Table 3) confirms some abrupt changes at the Bathonian-Callovian transition. But it also indicates a gradual change in the proportions of lithologies throughout the entire Jurassic. Moreover, the lowermost correlation value registered between the Sinemurian and Tithonian is just 0.54, which means an absence of fundamental changes in the character of deposition. It would be better to describe this as a major, but gradual turnover in the character of sedimentation during the entire Aalenian-Callovian transition.

Table 3

Correlation of the proportions of observed lithologies by Jurassic stages in the Greater Caucasus Basin

\begin{tabular}{|l|r|r|r|r|r|r|r|r|r|r|}
\hline Stages & \multicolumn{1}{c|}{ Sin } & \multicolumn{1}{c|}{ Pli } & \multicolumn{1}{c|}{ Toa } & \multicolumn{1}{c|}{ Aal } & \multicolumn{1}{c|}{ Baj } & \multicolumn{1}{c|}{ Bat } & \multicolumn{1}{c|}{ Cal } & \multicolumn{1}{c|}{ Oxf } & \multicolumn{1}{c|}{ Kim } & \multicolumn{1}{c|}{ Tit } \\
\hline Sin & 1.00 & 0.98 & 0.93 & 0.91 & 0.97 & 0.87 & 0.67 & 0.64 & 0.63 & 0.54 \\
\hline Pli & & 1.00 & 0.98 & 0.97 & 0.97 & 0.93 & 0.69 & 0.67 & 0.67 & 0.58 \\
\hline Toa & & & 1.00 & 1.00 & 0.94 & 0.96 & 0.70 & 0.67 & 0.68 & 0.59 \\
\hline Aal & & & & 1.00 & 0.93 & 0.97 & 0.75 & 0.71 & 0.73 & 0.64 \\
\hline Baj & & & & & 1.00 & 0.88 & 0.76 & 0.76 & 0.74 & 0.67 \\
\hline Bat & & & & & & 1.00 & 0.82 & 0.77 & 0.79 & 0.69 \\
\hline Cal & & & & & & & 1.00 & 0.99 & 0.99 & 0.96 \\
\hline Oxf & & & & & & & & 1.00 & 0.98 & 0.97 \\
\hline Kim & & & & & & & & & 1.00 & 0.98 \\
\hline Tit & & & & & & & & & & 1.00 \\
\hline
\end{tabular}

See Table 2 for abbreviations

\section{Changes in lithofacies proportions through time}

The Jurassic lithofacies proportions also changed significantly in the Greater Caucasus Basin (Fig. 3; Table 4). The proportion of siliciclastic lithofacies decreased in the Sinemurian-Bajocian, but increased in the Bathonian. This was followed by a gradual decline. The proportion of shale lithofacies was very high until the Bajocian, when it started to fall. In contrast, the carbonate lithofacies WS 
Table 4

Number of occurrences (upper number) and WS (lower number) of Jurassic lithofacies in the Greater Caucasus Basin

\begin{tabular}{|l|c|c|c|c|c|c|c|c|}
\hline \multirow{2}{*}{ Stage } & \multicolumn{9}{|c|}{ Lithofacies (predominant lithologies) } \\
\cline { 2 - 10 } & Cla & Sha & $\begin{array}{c}\text { Cla+ } \\
\text { Sha }\end{array}$ & Car & Eva & Coa & Vol & Sci \\
\hline Sin & 13 & 10 & 16 & - & - & - & 2 & - \\
$(16)$ & $\mathbf{8 1}$ & $\mathbf{6 3}$ & $\mathbf{1 0 0}$ & & & & $\mathbf{1 3}$ & \\
\hline Pli & 24 & 30 & 40 & - & - & - & 3 & - \\
$(40)$ & $\mathbf{6 0}$ & $\mathbf{7 5}$ & $\mathbf{1 0 0}$ & & & & $\mathbf{8}$ & \\
\hline Toa & 28 & 38 & 42 & - & - & - & 2 & - \\
$(43)$ & $\mathbf{6 5}$ & $\mathbf{8 8}$ & $\mathbf{9 8}$ & & & & $\mathbf{5}$ & \\
\hline Aal & 16 & 30 & 30 & 1 & - & - & 2 & - \\
$(31)$ & $\mathbf{5 2}$ & $\mathbf{9 7}$ & $\mathbf{9 7}$ & $\mathbf{3}$ & & & $\mathbf{6}$ & \\
\hline Baj & 11 & 20 & 20 & 1 & - & - & 10 & - \\
$(27)$ & $\mathbf{4 1}$ & $\mathbf{7 4}$ & $\mathbf{7 4}$ & $\mathbf{4}$ & & & $\mathbf{3 7}$ & \\
\hline Bat & 14 & 13 & 18 & - & - & 1 & 1 & - \\
$(18)$ & $\mathbf{7 8}$ & $\mathbf{7 2}$ & $\mathbf{1 0 0}$ & & & $\mathbf{6}$ & $\mathbf{6}$ & \\
\hline Cal & 9 & 7 & 10 & 11 & - & - & - & - \\
$(16)$ & $\mathbf{5 6}$ & $\mathbf{4 4}$ & $\mathbf{6 3}$ & $\mathbf{6 9}$ & & & & \\
\hline Oxf & 5 & 5 & 6 & 14 & - & - & - & - \\
$(16)$ & $\mathbf{3 1}$ & $\mathbf{3 1}$ & $\mathbf{3 8}$ & $\mathbf{8 8}$ & & & & \\
\hline Kim & 4 & 5 & 5 & 13 & 2 & - & - & - \\
$(16)$ & $\mathbf{2 5}$ & $\mathbf{3 1}$ & $\mathbf{3 1}$ & $\mathbf{8 1}$ & $\mathbf{1 3}$ & & & - \\
\hline Tit & 5 & 7 & 7 & 14 & 4 & - & - & - \\
$(19)$ & $\mathbf{2 6}$ & $\mathbf{3 7}$ & $\mathbf{3 7}$ & $\mathbf{7 4}$ & $\mathbf{2 1}$ & & & \\
\hline
\end{tabular}

In the "Stage" column, values in brackets below signify the entire numbers of formations. See Table 2 for abbreviations

was close to 0 in the Early-Middle Jurassic, whereas it rose abruptly in the Callovian-Oxfordian with a peak value of $88 \%$. A slight decline occurred later The WS values of other lithofacies were generally low during the Jurassic. Evaporite-dominated formations appear in the Kimmeridgian-Tithonian, whereas those dominated by volcaniclastics and volcanics prevail in the Sinemurian and the Bajocian.

Our results confirm a major change in lithofacies during the AalenianCallovian interval rather than an abrupt shift in the character of deposition at the Bathonian-Callovian transition. In contrast to lithologies, shale declines later than siliciclastics (Fig. 3). As in the case of lithologies, the percentage of combined siliciclastics and shale already declined since the Bajocian; this trend was also interrupted in the Bathonian (Table 4). However, the shift at the BathonianCallovian transition was sharper on the basis of lithofacies than that of lithologies (compare Tables 2 and 4). Comparing the correlation values for stages of the Sinemurian-Bathonian and the Callovian-Tithonian for lithofacies (Table 5), one can see a striking difference between them. The diversity of rock types in the Sinemurian-Bathonian and the Callovian-Tithonian intervals is better expressed by lithofacies than lithologies. The former interval was dominated by two main lithofacies, whereas three were predominant in the latter interval. The 
Table 5

Correlation of the proportions of observed lithofacies by Jurassic stages in the Greater Caucasus Basin. See Table 2 for abbreviations

\begin{tabular}{|c|c|c|c|c|c|c|c|c|c|c|}
\hline Stage & Sin & Pli & Toa & Aal & Baj & Bat & Cal & Oxf & Kim & Tit \\
\hline Sin & 1.00 & 0.96 & 0.94 & 0.87 & 0.82 & 0.99 & 0.55 & 0.16 & 0.10 & 0.16 \\
\hline Pli & & 1.00 & 1.00 & 0.98 & 0.90 & 0.98 & 0.53 & 0.17 & 0.13 & 0.21 \\
\hline Toa & & & 1.00 & 0.98 & 0.89 & 0.97 & 0.53 & 0.18 & 0.15 & 0.23 \\
\hline Aal & & & & 1.00 & 0.91 & 0.92 & 0.51 & 0.20 & 0.18 & 0.26 \\
\hline Baj & & & & & 1.00 & 0.83 & 0.38 & 0.10 & 0.06 & 0.12 \\
\hline Bat & & & & & & 1.00 & 0.55 & 0.17 & 0.11 & 0.18 \\
\hline Cal & & & & & & 1.00 & 0.91 & 0.87 & 0.87 \\
\hline Oxf & & & & & & & & 1.00 & 0.98 & 0.95 \\
\hline Kim & & & & & & & & 1.00 & 0.99 \\
\hline Tit & & & & & & & & & 1.00 \\
\hline
\end{tabular}

See Table 2 for abbreviations

dominance of volcanics and volcaniclastics in the Early-Middle Jurassic is incomparably less than that of carbonates in the Upper Jurassic.

\section{Changes in siliciclastic rock proportions through time}

Table 6 summarizes the changes in relative amounts of the principal siliciclastic lithologies. In the Sinemurian, siliciclastic rocks in the Greater Caucasus Basin were represented by comparable percentages of conglomerate, sandstone and siltstone. However, the importance of conglomerate began to decrease from the Pliensbachian onward and remained below 55\% until the Late Jurassic. The relative abundance of siltstone, in contrast, increased in the Toarcian-Aalenian and then dropped gradually. The Callovian is exceptional because regional siliciclastic deposition was dominated by sand in this stage. In the Late Jurassic, the importance of sandstone decreased and became comparable with that of conglomerate.

Episodes of siliciclastic coarsening occurred in the Sinemurian and the Kimmeridgian but the overall sedimentation character in each was very different. Whereas deposition of siliciclastics and shale prevailed in the Sinemurian, that of carbonates and evaporites characterized the Kimmeridgian (Fig. 3). This requires a special explanation (see below). As for the only episode of siliciclastic fining, which occurred in the Toarcian-Aalenian, it corresponded well with an increase in the proportion of shale (Fig. 3). 


\section{Discussion}

Correlation of changes in sedimentary rock proportions with transgressions, regressions, and average basin depth

A rapid transgression occurred in the Greater Caucasus Basin during the Sinemurian-Pliensbachian after which the shoreline remained stable until the Bajocian, when a regression began that continued through the Bathonian (Fig. 4). A second transgression, more extensive than the former one, occurred in the Callovian-Kimmeridgian interval. A regression occurred in the Tithonian, but the basin remained very large. This regional transgressive-regressive pattern corresponds generally to the global eustatic changes reported by Haq et al. (1987), Hallam (1988, 2001), and Haq and Al-Qahtani (2005) (Fig. 4). The correlation values (indicated in brackets below) between proportions of the three main lithologies and $\mathrm{Tg}$ (index of transgression) differ strongly. The siliciclastic WS increases together with a regression $(-0.61)$ as does the WS for shale $(-0.46)$. However, the WS of carbonates increases with transgression $(+0.75)$. Very similar conclusions can be made for siliciclastic lithofacies $(-0.87)$, shale lithofacies $(-0.67)$ and carbonate lithofacies $(+0.78)$. The transgressive environments seem to be slightly more favorable for accumulation of conglomerate $(+0.20)$, but

\section{GREATER CAUCASUS BASIN}

GLOBAL CURVES

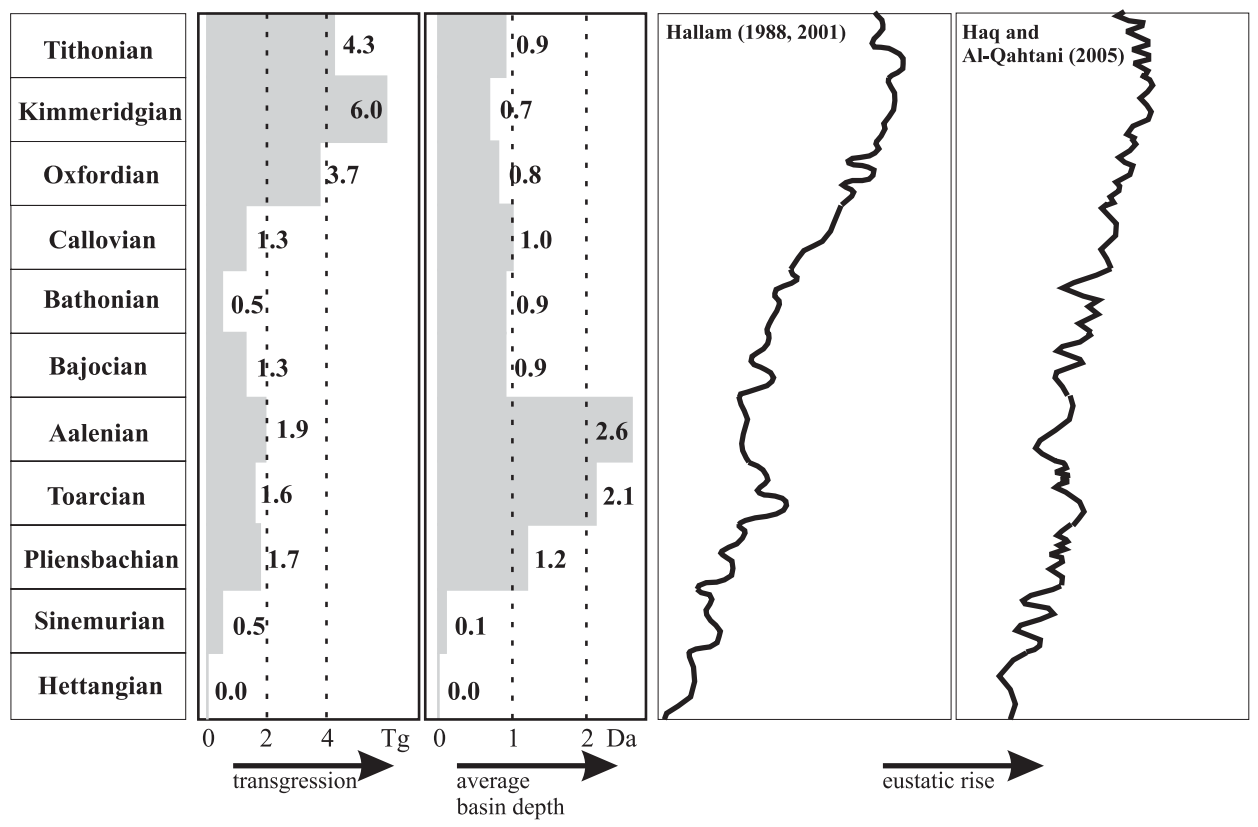

Fig. 4

Transgressions, regressions, and average basin depth of the Greater Caucasus Basin in relation to the global eustasy 
unfavorable for accumulation of sand $(-0.88)$ and silt $(-0.54)$. A negative correlation occurs between proportion of shale and transgressions that requires further explanation. In fact, one can observe that shale WS was high both at the beginning of a transgression in the Sinemurian and at its maximum in the Aalenian.

The average basin depth increased in the Greater Caucasus Basin during the entire Sinemurian-Aalenian interval (Fig. 4). The average depth then decreased abruptly, and the basin remained relatively shallow until the end of the Jurassic. These changes do not coincide with the global eustatic curves by Haq et al. (1987), Hallam $(1988,2001)$ and Haq and Al-Qahtani (2005). The correlation values between proportions of the three main lithologies and Da differ markedly again. The siliciclastic WS increases together with a relative deepening $(+0.34)$ and the same finding is true for for shale $(+0.42)$. However, WS of carbonates increases along with a relative shallowing $(-0.50)$. Similar conclusions can be made for siliciclastic lithofacies $(+0.03)$, shale lithofacies $(+0.67)$, and carbonate lithofacies $(-0.32)$. Relative shallowing appears to be favorable for accumulation of conglomerates $(-0.65)$, but unfavorable for accumulation of sandstone $(+0.24)$ and siltstone $(+0.56)$. In any case, a correlation between proportions of lithologies and Da (index of average basin depth) is generally weaker than a correlation between proportions of lithologies and $\mathrm{Tg}$. Thus, transgressions and regressions were more important controls of changes in sedimentary proportions. Our data also suggest that the larger extent of the shallower Caucasian Sea (sensu Ruban 2006b) explained the Kimmeridgian siliciclastic coarsening noted above.

A greater diversity of sedimentation (in terms of the number of principal lithofacies) typifies the Callovian-Tithonian interval compared to the Sinemurian-Pliensbachian interval. It was coeval to a major shoreline shift and submergence of large areas, when shallow-marine conditions prevailed (Fig. 4). One can hypothesize that as the submerged area increases, the variability among the regional sedimentary settings will also increase. Do our quantitative evaluations suggest that a dominance of shallow-marine environments is also responsible for higher sedimentary diversity? Perhaps sedimentary differentiation, physical destruction, and chemical dissolution were less efficient on a shelf than on a slope. In other words, sedimentary processes are not finalized, or even terminated, on a shelf. Therefore, the sediments preserved in the shallow-marine setting are expected to be more diverse. But it is also necessary to remember that deep-water environments also remained in some parts of the Greater Caucasus Basin during the Late Jurassic (Ruban 2007a). Thus, a higher sedimentary diversity of this epoch could be also a result of a sharp bathymetric gradient in the basin. It is important to take in consideration parameters of sedimentary influx to the basin as well as conditions for authigenic mineral growth and biotic production. This remains a task for further studies. 


\section{Tectonic control}

Regional tectonic activity is always an important control of sedimentation. Its balance with global eustasy is responsible for regional transgressions, regressions, and changes in the basin depth. The Jurassic tectonic evolution of the Greater Caucasus Basin has recently been reviewed by Ershov et al. (2003), Kazmin and Tikhonova (2006), Ruban (2006b, 2007b, 2008a), Saintot et al. (2006) and Tawadros et al. (2006). A collision between the Greater Caucasus Terrane and Baltica resulted in a regional orogeny in the latest Triassic-earliest Jurassic, which followed this terrane displacement along a major shear zone. A back-arc basin began to open in the Sinemurian, and the opening lasted until the Bajocian. The interpretation of the Bajocian-Bathonian tectonic events in the Greater Caucasus is controversial. Ershov et al. (2003) and Saintot et al. (2006) suggested an orogeny and a partial closure of the Greater Caucasus Trough. According to Kazmin and Tikhonova (2006) it is difficult to explain such an orogeny. Ruban (2006b) hypothesized a collision between the Northern Transcaucasian Arc and the Southern Transcaucasian Arc that was resulted in a formation of the united Transcaucasian Arc in the Bajocian-Bathonian. The onset of a regression in the Aalenian (Ruban 2007a) suggests that such a collision might have started earlier, i.e. at the end of the Aalenian. During the Callovian-Tithonian, the tectonic regime of the Greater Caucasus Basin was quite stable. Some extension might have occurred (Ershov et al. 2003), and Saintot et al. (2006) interpreted this time interval to be a post-rift phase in the basin evolution.

The orogeny, which occurred in the latest Triassic-earliest Jurassic, explains the high proportion of siliciclastic lithologies and lithofacies documented above (Tables 2,4). This tectonic event was responsible for abundant conglomerate deposition in the Sinemurian (Table 6). Similarly, the Bathonian, although the sediments of this age are not distributed widely, is marked by an increase in the proportion of siliciclastic lithologies (Table 2) and lithofacies (Table 4). But why were the WS values less high in the Callovian? If an orogeny had occurred in the Bathonian, it would have led to an increase in siliciclastic deposition in the Callovian, as happened after the earliest Jurassic orogeny. But this did not occur in the Callovian. Moreover, we do not observe any remarkable increase in the proportion of the coarse siliciclastics either in the Bathonian or in the Callovian (Table 6). An arc-arc collision since at least the Bajocian may provide a better explanation (Ruban 2006b, 2008a). This would require lesser tectonic forces than those acting in the earliest Jurassic. The arc-arc collision could also be responsible for some perturbation in the sedimentary rock proportions during the Middle Jurassic. It seems that active volcanism within the Caucasian arcs could also be an important control on sedimentation. Intensive volcanism might have led to subsequent shedding of coarse-grained volcanic-derived detritus into the basin. This is confirmed by the results of the present study (Tables 2, 6). However, a coincidence between episodes of coarse clastic deposition and volcanism might have also been occasional. The growth of arcs might result an increase in delivery 
Table 6

Number of occurrences (upper number) and WS (lower number) of Jurassic siliciclastic lithologies in the Greater Caucasus Basin

\begin{tabular}{|l|c|c|c|}
\hline \multirow{2}{*}{ Stage } & \multicolumn{3}{|c|}{ Siliciclastic lithologies } \\
\cline { 2 - 4 } & Conglomerates & Sandstones & Siltstones \\
\hline Sin & 14 & 16 & 12 \\
$(16)$ & $\mathbf{8 8}$ & $\mathbf{1 0 0}$ & $\mathbf{7 5}$ \\
\hline Pli & 20 & 36 & 29 \\
$(38)$ & $\mathbf{5 3}$ & $\mathbf{9 5}$ & $\mathbf{7 6}$ \\
\hline Toa & 16 & 41 & 37 \\
$(42)$ & $\mathbf{3 8}$ & $\mathbf{9 8}$ & $\mathbf{8 8}$ \\
\hline Aal & 13 & 28 & 26 \\
$(30)$ & $\mathbf{4 3}$ & $\mathbf{9 3}$ & $\mathbf{8 7}$ \\
\hline Baj & 8 & 19 & 10 \\
$(20)$ & $\mathbf{4 0}$ & $\mathbf{9 5}$ & $\mathbf{5 0}$ \\
\hline Bat & 9 & 15 & 8 \\
$(17)$ & $\mathbf{5 3}$ & $\mathbf{8 8}$ & $\mathbf{4 7}$ \\
\hline Cal & 4 & 11 & 3 \\
$(11)$ & $\mathbf{3 6}$ & $\mathbf{1 0 0}$ & $\mathbf{2 7}$ \\
\hline Oxf & 5 & 7 & 3 \\
$(10)$ & $\mathbf{5 0}$ & $\mathbf{7 0}$ & $\mathbf{3 0}$ \\
\hline Kim & 8 & 8 & 3 \\
$(12)$ & $\mathbf{6 7}$ & $\mathbf{6 7}$ & $\mathbf{2 5}$ \\
\hline Tit & 7 & 7 & 4 \\
$(11)$ & $\mathbf{6 4}$ & $\mathbf{6 4}$ & $\mathbf{3 6}$ \\
\hline
\end{tabular}

In this case, lower values are percentages of particular siliciclastic lithologies among all siliciclastic rocks. In the "Stage" column, values in brackets are the total numbers of formations with siliciclastic lithologies. See Table 2 for abbreviations of detritus to the basin due to an increase in erosion. The abovementioned fundamental change in the character of sedimentation during the Aalenian-Callovian interval can be explained with a change from the very active tectonic regime in the Early-Middle Jurassic to calmer extensional tectonics in the Late Jurassic.

\section{Conclusions}

This quantitative study of the Jurassic sedimentary evolution of the Greater Caucasus Basin demonstrated the lithodiversity dynamics and yields a number of important conclusions:

1. the principal Jurassic lithologies and lithofacies in the Greater Caucasus Basin are siliciclastics, shale, and carbonates;

2. the changes from siliciclastic-andshale-dominated sedimentation to carbonate-dominated sedimentation occurred during the AalenianCallovian;

3. transgressions and regressions were more important controls of changes in the sedimentary rock proportions than average basin depth;

4. an extended area of the marine basin, its lower average depth, and a sharp bathymetric gradient were favorable for a higher diversity of sedimentation;

5. tectonic controls, which included the Late Triassic-Early Jurassic orogeny, the Bajocian-Bathonian arc-arc collision, and the Late Jurassic post-rift phase, had an important effect on the sedimentary rock proportions.

The Jurassic Greater Caucasus Basin, chosen as a subject for this case study, provides a lot of information for further comparison with that from other backarc basins. When particular tectonic events mask the general trends, a comparison of quantitative data from many basins may help to reveal them. 


\section{Acknowledgements}

The author gratefully thanks J. Haas (Hungary) and J. Pálfy (Hungary) for their thorough reviews, the "CEG" editorial staff for their support, N.W. Jones (USA) for his very valuable improvements to this paper, G.G. Lash (USA) for his correction of the earlier version of the latter, and K.B. Oheim (USA) for her technical support. The enthusiastic help with literature by M. Bécaud (France), N.M.M. Janssen (the Netherlands), W. Riegraf (Germany), and A. Schoonmaker (USA) is highly appreciated.

\section{References}

Boggs, S. Jr. 2006: Principles of Sedimentology and Stratigraphy. - Pearson Prentice Hall, Upper Saddle River. 662 p.

Catuneanu, O. 2006: Principles of Sequence Stratigraphy. - Elsevier, Amsterdam. 375 p.

Catuneanu, O., V. Abreu, J.P. Bhattacharya, M.D. Blum, R.W. Dalrymple, P.G. Eriksson, C.R. Fielding, W.L. Fisher, W.E. Galloway, M.R. Gibling, K.A. Giles, J.M. Holbrook, R. Jordan, C.G.St.C. Kendall, B. Macurda, O.J. Martinsen, A.D. Miall, J.E. Neal, D. Nummedal, L. Pomar, H.W. Posamentier, B.R. Pratt, J.F. Sarg, K.W. Shanley, R.J. Steel, A. Strasser, M.E. Tucker, C. Winker 2009: Towards the standardization of sequence stratigraphy. - Earth-Science Reviews, 92, pp. 1-33.

Chamley, H. 1989: Clay Sedimentology. - Springer, Berlin. 623 p.

Dercourt, J., M. Gaetani, B. Vrielynck, E. Barrier, B. Biju-Duval, M.-F. Brunet, J.P. Cadet, S. Crasquin, M. Sandulescu 2000: Atlas Peri-Tethys Palaeogeogeographic maps, vol. I-XX. - CCGM/CGMW, Paris, pp. 1-269. 24 maps and explanatory note.

Efendiyeva, M.A., D.A. Ruban 2009: Kavkaz v mezozoe i kajnozoe - geodinamitcheskie analogi i novye voprosy [The Caucasus in the Mesozoic and the Cenozoic - geodynamical analogs and new challenges]. - Azerbaijan Oil Industry, 2, pp. 9-13. (In Russian)

Ershov, A.V., M.-F. Brunet, A.M. Nikishin, S.N. Bolotov, B.P. Nazarevich, M.V. Korotaev 2003 Northern Caucasus basin: thermal history and synthesis of subsidence models. - Sedimentary Geology, 156, pp. 95-118.

Fagel, N. 2007: Clay Minerals, Deep Circulation and Climate. - In: Hillaire-Marcel, C., A. Vernal (Eds): Proxies in Late Cenozoic paleoceanography. Elsevier, Amsterdam, pp. 139-184.

Golonka, J. 2004: Plate tectonic evolution of the southern margin of Eurasia in the Mesozoic and Cenozoic. - Tectonophysics, 381, pp. 235-273.

Granovskij, A.G., M.M. Ryshkov, E.M. Pushkarskij 2001: Geodinamitcheskie aspekty formirovanija ranne-srednejurskikh otlozhenij Severo-Zapadnogo Kavkaza [Geodynamical aspects of formation of the Early-Middle Jurassic deposits of the North-Western Caucasus]. - Izvestija Vysshikh Utchebnykh Zavedenij. Severo-Kavkazskij Region. Estestvennye nauki, 2, pp. 71-74. (In Russian)

Hallam, A. 1988: A re-evaluation of Jurassic eustasy in the light of new data and the revised Exxon curve. - In: Wilgus, C.K., B.S. Hastings, C.G.St.C. Kendall, H.W. Posamentier, C.A. Ross, J.C. Van Wagoner (Eds): Sea-Level Changes - An Integrated Approach. Society for Economic Paleontologists and Mineralalogists Special Publication, 42, pp. 261-273.

Hallam, A. 2001: A review of the broad pattern of Jurassic sea-level changes and their possible causes in the light of current knowledge. - Palaeogeography, Palaeoclimatology, Palaeoecology, 167, pp. 23-37.

Haq B.U., A.M. Al-Qahtani 2005: Phanerozoic cycles of sea-level change on the Arabian Platform. GeoArabia, 10, pp. 127-160. 
Haq, B.U., J. Hardenbol, P.R. Vail 1987: Chronology of Fluctuating Sea Levels Since the Triassic. Science, 235, pp. 1156-1167.

Jasamanov, N.A. 1978: Landshaftno-klimatitcheskie uslovija jury, mela i paleogena Juga SSSR [Landscape and climatic conditions of the Jurassic, the Cretaceous and the Paleogene of the South of the USSR]. - Nedra, Moskva. 224 p. (In Russian)

Kazmin, V.G., N.F Tikhonova 2006: Evolution of Early Mesozoic back-arc basins in the Black SeaCaucasus segment of a Tethyan active margin. - In: Robertson, A.H.F., D. Mountrakis (Eds): Tectonic Development of the Eastern Mediterranean Region. Geological Society, London, Special Publication, 260, pp. 179-200.

Kendall, M.G. 1970: Rank Correlation Methods. - Griffin, London. 202 p.

Kuznetsov, V.G. 1993: Late Jurassic - Early Cretaceous carbonate platform in the northern Caucasus and Precaucasus. - In: Simo, J.A.T, R.W. Scott, J.-P. Masse (Eds): Cretaceous Carbonate Platforms. AAPG Memoir, 56, pp. 455-463.

Ogg, J.G., G. Ogg, F.M. Gradstein 2008: The Concise Geologic Time Scale. - Cambridge University Press, Cambridge. $177 \mathrm{p}$.

Peters, S.E. 2006: Macrostratigraphy of North America. - Journal of Geology, 114, pp. 391-412.

Prozorovskaya, E.L. (Ed.) 1979: Stratigrafitcheskij slovar' SSSR. Trias, jura, mel [Stratigraphical dictionary of the USSR. Triassic, Jurassic, Cretaceous]. - Nedra, Leningrad. 592 p. (In Russian)

Ronov, A.B., V.E. Khain, A.N. Balukhovsky, K.B. Seslavinsky 1980: Quantitative analysis of Phanerozoic sedimentation. - Sedimentary Geology, 25, pp. 311-325.

Rostovtsev, K.O., V.B. Agaev, N.R. Azarjan, R.G. Babaev, N.V. Beznosov, T.A. Gasanov, V.I. Zesashvili, M.G. Lomize, T.A. Paitchadze, D.I. Panov, E.L. Prosorovskaya, A.S. Sakharov, V.A. Todria, M.V. Toptchishvili, M.R. Abdulkasumzade, A.S. Avanesjan, V.S. Belenkova, N.S. Bendukidze, V.Â. Vuks, M.P. Doludenko, A.I. Kiritchkova, V.G. Klikushin, G.Â. Krymgol'ts, G.M. Romanov, T.V. Shevtchenko 1992: Jura Kavkaza [Jurassic of the Caucasus]. - Nauka, Sankt-Peterburg. 185 p. (In Russian)

Ruban, D.A. 2004: Diversity dynamics of Early-Middle Jurassic brachiopods of Caucasus, and the Pliensbachian-Toarcian mass extinction. - Acta Palaeontologica Polonica, 49, pp. 275-282.

Ruban, D.A. 2005: Rises of the macrobenthos diversity and the Paleozoic - Mesozoic rimmed shelves in the northern Caucasus. - The First International Scientific Conference of Young Scientists and Students: "New Directions of Investigations in Earth Sciences". Abstracts. Baku. p. 113.

Ruban, D.A. 2006a: Taxonomic diversity dynamics of the Jurassic bivalves in the Caucasus: Regional trends and recognition of global patterns. - Palaeogeography, Palaeoclimatology, Palaeoecology, 239, pp. 63-74.

Ruban, D.A. 2006b: The Palaeogeographic Outlines of the Caucasus in the Jurassic: The Caucasian Sea and the Neotethys Ocean. - Geološki anali Balkanskoga poluostrva, 67, pp. 1-11.

Ruban, D.A. 2007a: Jurassic transgressions and regressions in the Caucasus (northern Neotethys Ocean) and their influences on the marine biodiversity. - Palaeogeography, Palaeoclimatology, Palaeoecology, 251, pp. 422-436.

Ruban, D.A. 2007b: Major Paleozoic-Mesozoic Unconformities in the Greater Caucasus and Their Tectonic Re-Interpretation: A Synthesis. - GeoActa, 6, pp. 91-102.

Ruban, D.A. 2008a: The Jurassic events in the Greater Caucasus Basin (Northern Neotethys) and the Neuquén Basin (West Gondwana). - Revista de la Asociación Geológica Argentina, 63, pp. $766-775$.

Ruban, D.A. 2008b: Jurassic maximum flooding surfaces in the Greater Caucasus Basin (Northern Neo-Tethys). - Central European Geology, 51, pp. 99-112.

Ruban, D.A., J. Tyszka 2005: Diversity dynamics and mass extinctions of the Early-Middle Jurassic foraminifers: A record from the Northwestern Caucasus. - Palaeogeography, Palaeoclimatology, Palaeoecology, 222, pp. 329-343.

Saintot, A., M.-F. Brunet, F. Yakovlev, M. Sébrier, R. Stephenson, A. Ershov, F. Chalot-Prat, T. McCann 2006: The Mesozoic-Cenozoic tectonic evolution of the Greater Caucasus. - In: Gee, D.G., R.A. 
Stephenson (Eds): European Lithosphere Dynamics. Geological Society, London, Memoir 32, pp. 277-289.

Salvador, A. (Ed.) 1994: International Stratigraphic Guide. A Guide to Stratigraphic Classification, Terminology, and Procedure. - International Subcommission on Stratigraphic Classification, Geological Society of America. $214 \mathrm{p}$.

Scotese, C.R. 2004: A continental drift flipbook. - Journal of Geology, 112, pp. 729-741.

Stampfli, G.M., G.D. Borel 2002: A plate tectonic model for the Paleozoic and Mesozoic constrained by dynamic plate boundaries and restored synthetic oceanic isochrons. - Earth and Planetary Science Letters, 196, pp. 17-33.

Tawadros, E., D. Ruban, M. Efendiyeva 2006: Evolution of NE Africa and the Greater Caucasus: Common Patterns and Petroleum Potential. - The Canadian Society of Petroleum Geologists, the Canadian Society of Exploration Geophysicists, the Canadian Well Logging Society Joint Convention. May 15-18, 2006. Calgary. pp. 531-538.

Veeken, P.C.H. 2006: Seismic Stratigraphy, Basin Analysis and Reservoir Characterisation. - Elsevier, Amsterdam. 509 p.

Velde, B. 1992: Introduction to Clay Minerals. - Chapman and Hall, London. 198 p.

Velde, B. 1995: Origin and Mineralogy of Clays. Clays and the environment. - Springer, Berlin. $356 \mathrm{p}$.

Weaver, C.E. 1989: Clays, Muds, and Shales. - Elsevier, Amsterdam. 819 p. 


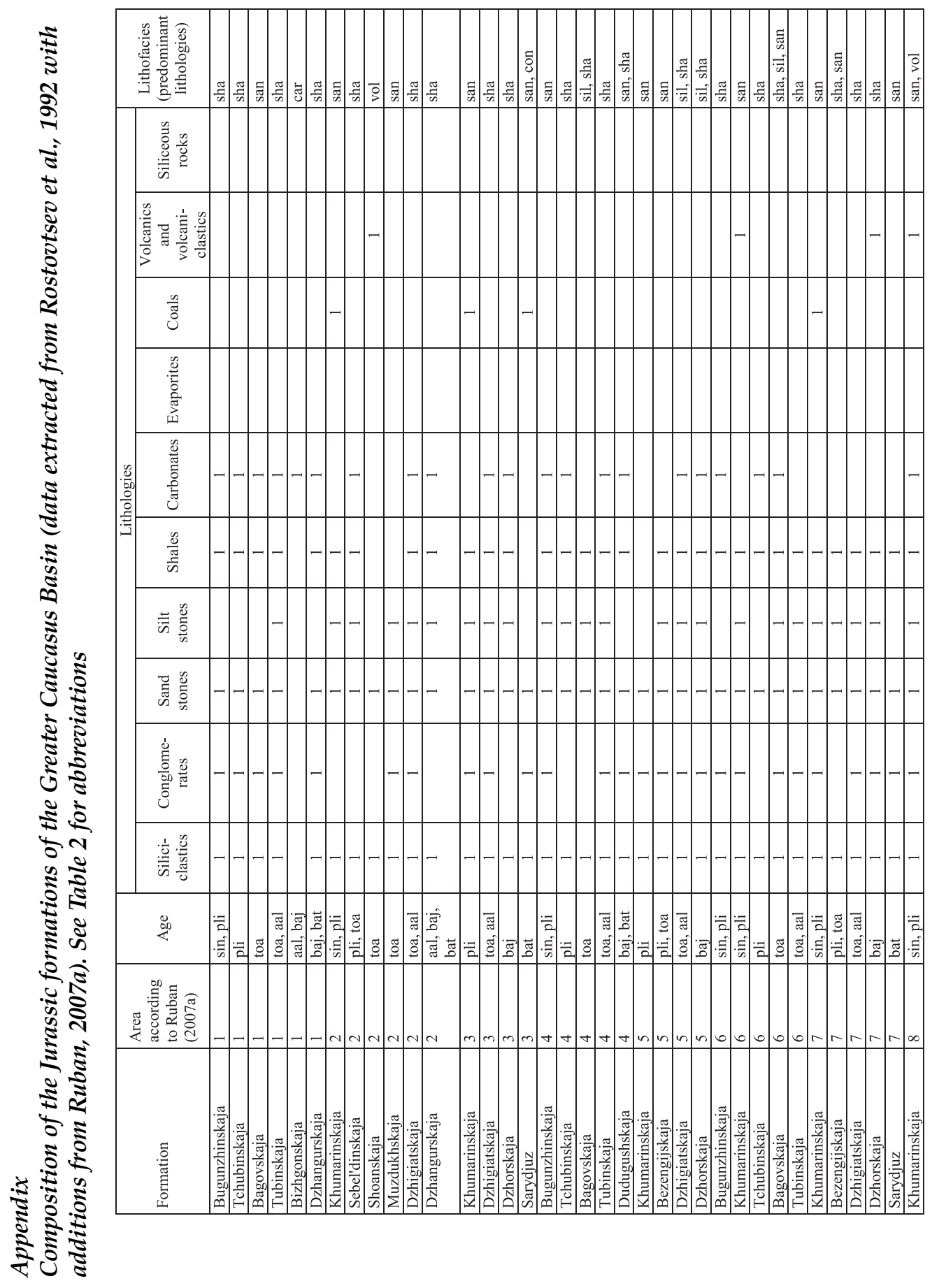

Central European Geology 52, 2009 


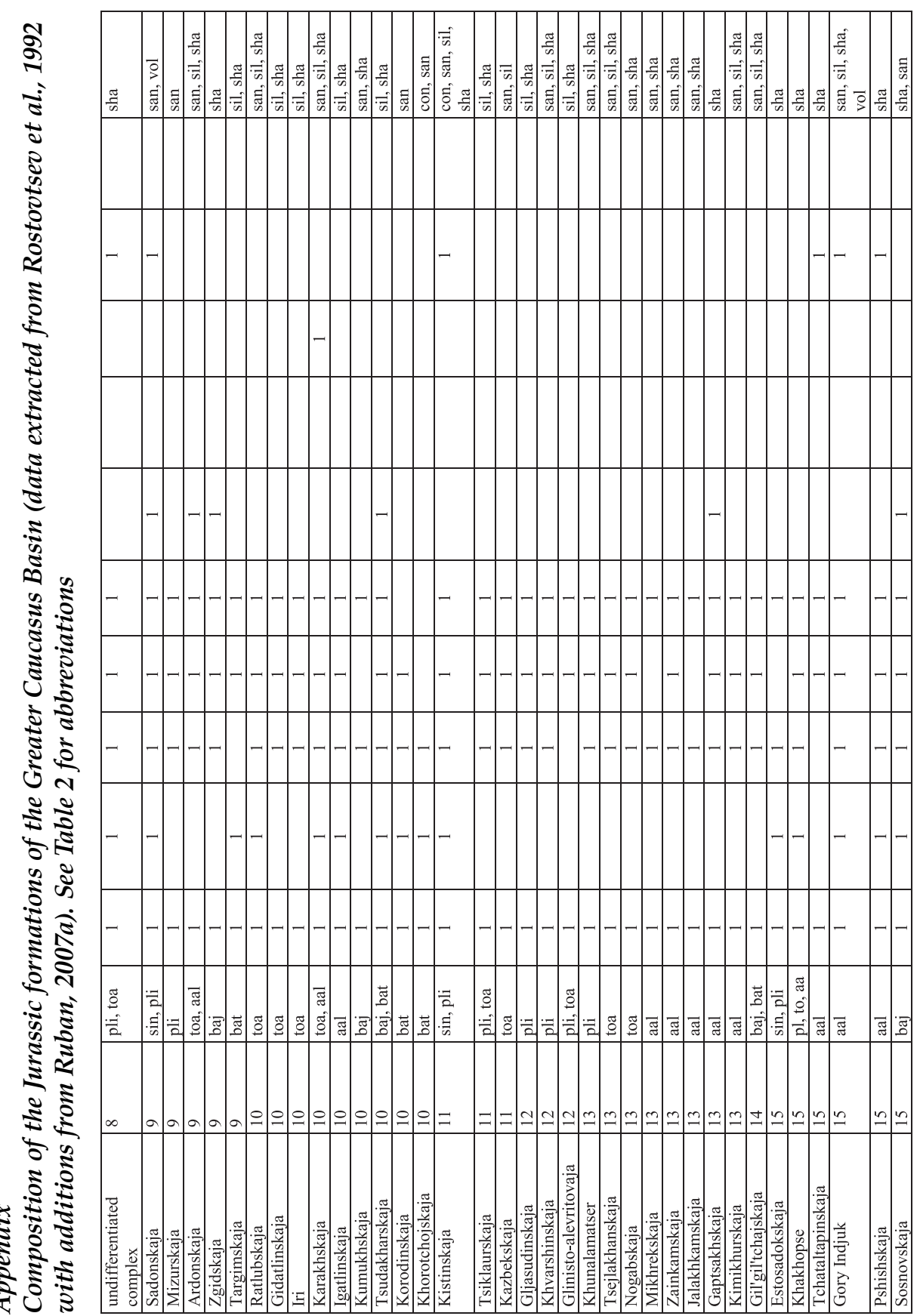




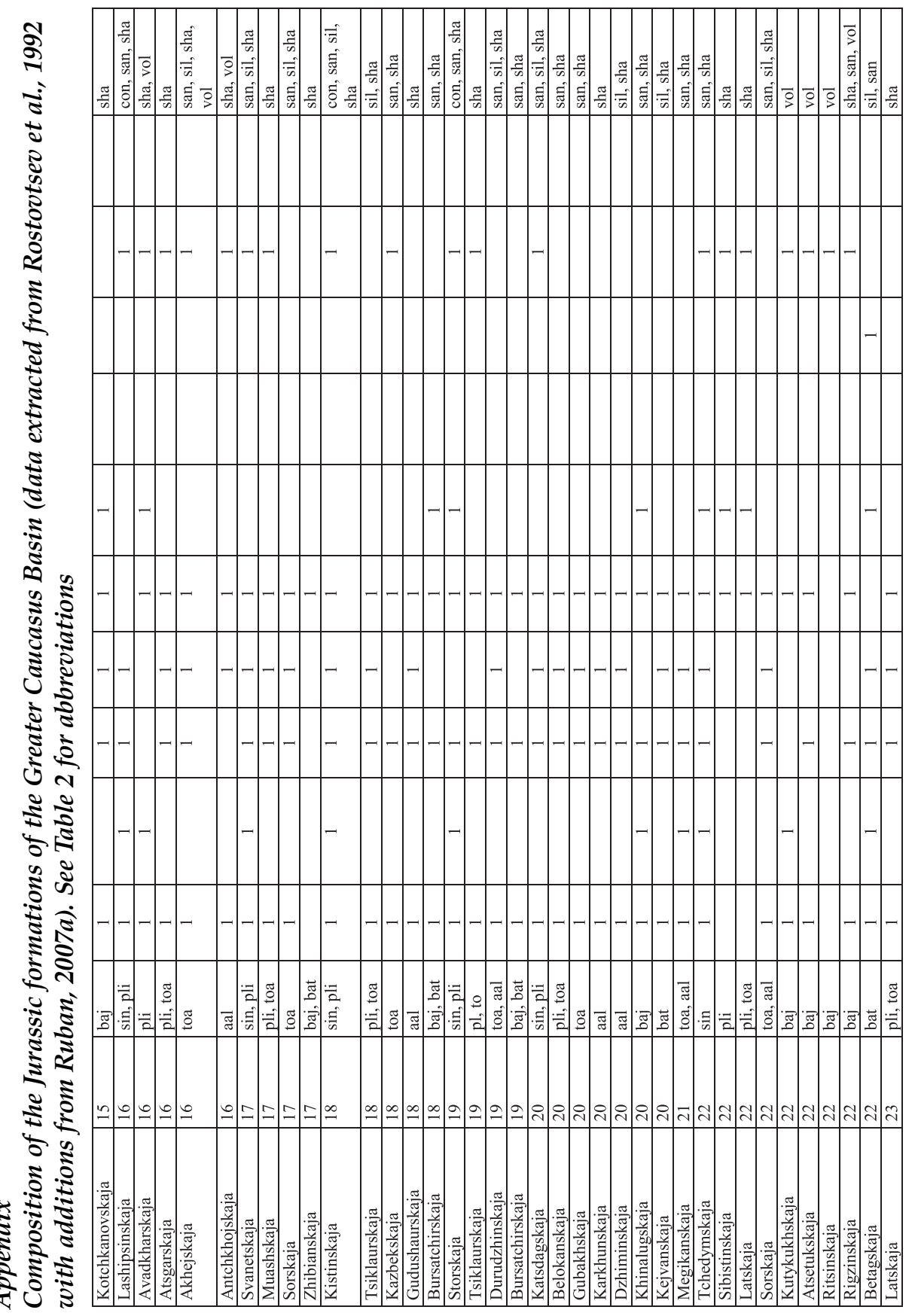




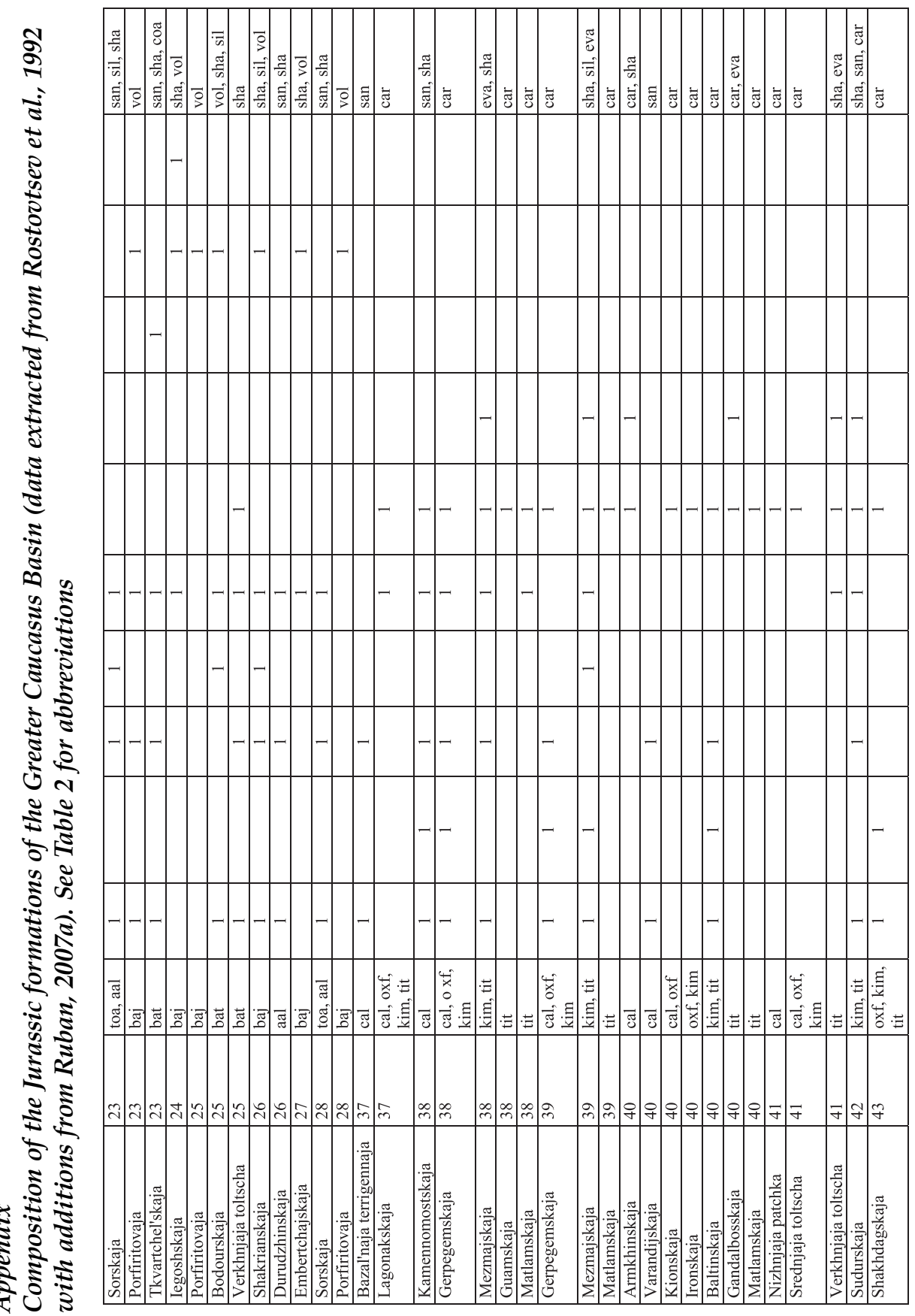


96 D. A. Ruban

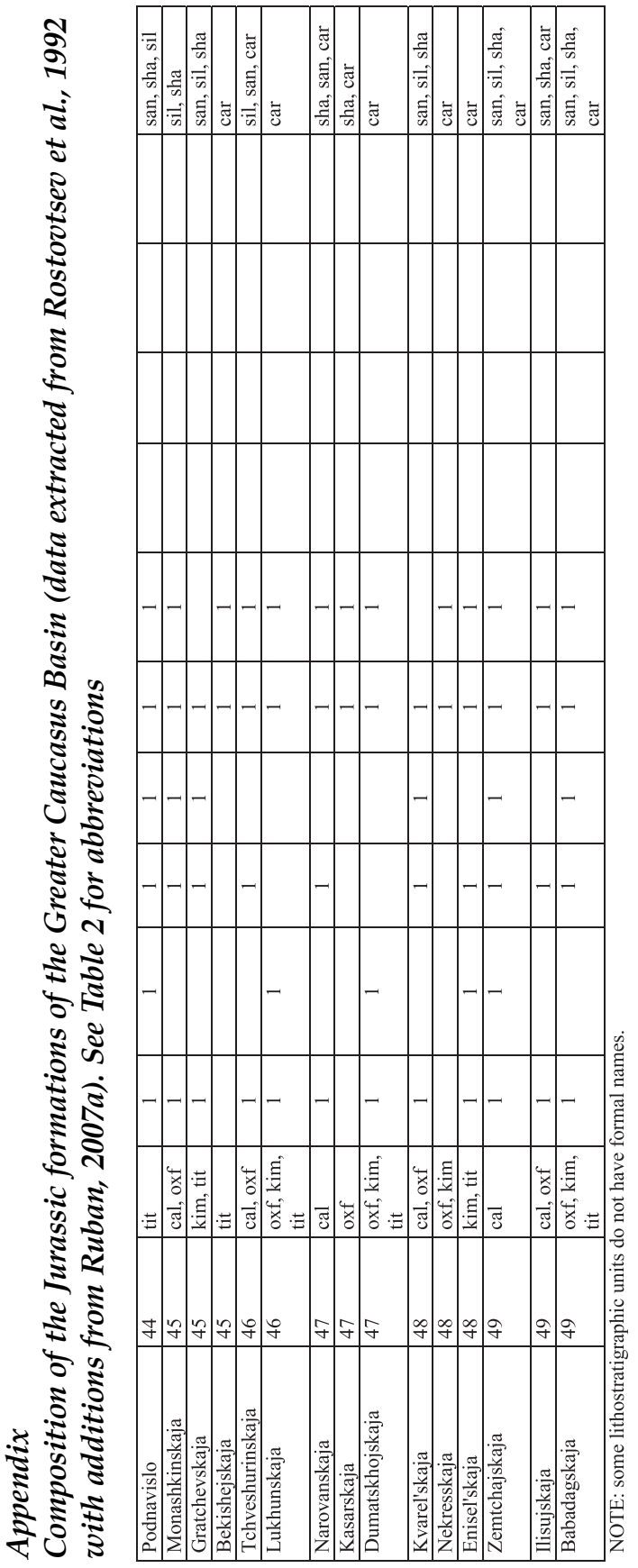

Central European Geology 52, 2009 